\title{
Mechanisms of Relaxation of Electronic Excitation of Triazido-S-triazine
}

\author{
P.O. Kondratenko ${ }^{1}$, Yu.M. Lopatkin'2, T.M. Sakun ${ }^{1}$ \\ ${ }^{1}$ National Aviation University, 1, Liubomyr Huzar ave., 03058 Kyiv, Ukraine \\ 2 Sumy State University, 2, Rymsky-Korsakov St., 40007 Sumy, Ukraine
}

(Received 16 July 2021; revised manuscript received 20 October 2021; published online 25 October 2021)

\begin{abstract}
The discovery of fullerenes and the identification of carbon nanotubes became a stage in the development of materials science, instrumentation, and new nanotechnology. As a result of studies of the mechanisms of electronic excitation relaxation in symmetric molecules of triazido-S-triazine, it is shown that the $\mathrm{C}_{3}$ symmetry of the molecule determines the fact that the energy levels of the excited states are treefold. Among the triplet states, the first three $\Pi \Pi^{*}$-states have the lowest energy, followed by three $п \sigma^{*}$ states. Among the singlet states, the first three $\Pi \sigma^{*}$-states have the lowest energy. The following states are $\Pi \Pi^{*}$-states responsible for the UV absorption spectra of the molecule. The excitation of a molecule into these states quickly relaxes into $п \sigma^{*}$-states from which the processes of dissociation of the molecule are possible. On the other hand, the $п \sigma^{*}$-configuration of singlet states facilitates the rapid conversion of the molecule into triplet $\Pi \sigma^{*}$-states. It is shown that the configurational interaction between three local $\Pi \sigma^{*}$. states leads to the creation of three delocalized molecular orbitals (MO). This creates three energy levels of the excited state, the lowest of which corresponds to the MO, which has $\mathrm{C}_{3}$ symmetry. The other two MOs have reduced symmetry, and therefore they are responsible for the dissociation of the molecule. It turned out that states $\mathrm{T}_{5}$ and $\mathrm{S}_{3}$ have a dissociative potential surface. The interaction between the states causes a decrease in the quantum yield of the photodissociation of the molecule.
\end{abstract}

Keywords: Relaxation of electronic excitation, Highly excited states, Dissociative potential surface, Configurational interaction, Photodissociation of azides.

DOI: 10.21272/jnep.13(5).05009

PACS numbers: 31.50.Df, 82.20.Wt

\section{INTRODUCTION}

There are many groups of starting compounds used for the functionalization of nanotubes and nanofibers [1-7], including those from the triazide family. In this paper, we investigate the physical and photochemical properties of one of the representatives of this family triazido-s-triazine.

The behavior of molecules in highly excited states is an urgent fundamental problem of modern physics and technology. Until now, very little attention has been paid to the relaxation processes of molecule excitation. It was believed that the laws of photochemistry work invariably, including the fourth law, which states that in the vast majority of photochemical processes occurring in solutions of organic molecules only molecules excited into $\mathrm{S}_{1}$ or $\mathrm{T} 1$ states are involved [8].

For a long time it was believed that it should be so, since relaxation processes are mostly fast and nonequilibrium, and all possible equilibrium processes can occur only with the participation of $\mathrm{S}_{1}$ or $\mathrm{T}_{1}$ states of the molecule. Although the fact of fading of dyes on fabrics under the influence of solar radiation is well known. Subsequently, numerous experimental data have emerged that show that the processes of excitation relaxation do not interfere with the processes important for science and practice in highly excited states: the generation of current carriers, photochemical and radiation-chemical processes, etc.

In studies of photochemical processes in methylene blue and resazurin conducted by the authors in [9], it was shown that the dye has no photochemical activity in the long-wavelength absorption band $(\lambda=667 \mathrm{~nm})$ at low excitation intensities, but has photochemical activity at high intensities (two-quantum processes) of light in the visible range, or at arbitrary intensities in the ultraviolet region of the spectrum $(\lambda \leq 330 \mathrm{~nm})$. Thus, photochemical transformations of molecules are carried out in a highly excited state.

Another group of processes is known, which was found in the study of the spectral sensitivity of the processes of photodissociation of azides of the malachite green dye [8]. In this case, it turned out that upon irradiation of a solution of these azides with monochromatic light from the region of the long-wavelength absorption band, the quantum yield of photodissociation did not exceed 0.01 , while when irradiated with light with $\lambda<\lambda_{c r}\left(\lambda_{c r}=350 \mathrm{~nm}\right)$, the yield increased significantly (almost to one at low temperatures). The research of the photochemical properties of a number of molecular systems [9] showed that these processes occur in highly excited states in all molecules. Thus, the existence of quasi-equilibrium relaxation processes of electronic excitation of molecules was proved.

In this work we continue to study quasi-equilibrium processes of electronic relaxation from highly excited states in the molecule of triazido-S-triazine (TAT):

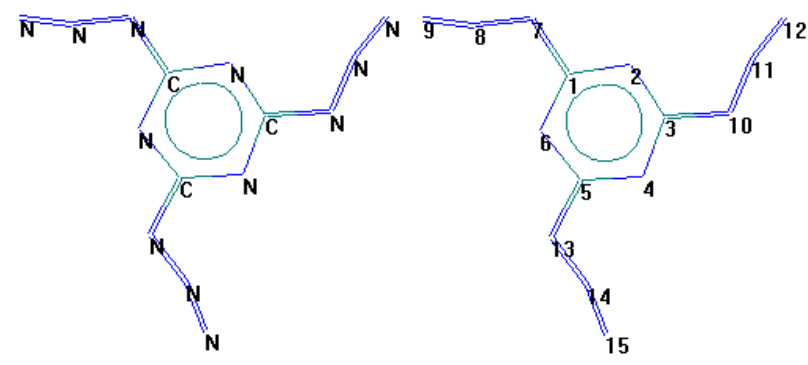




\section{ENERGY STRUCTURE OF THE TRIAZIDO-S- TRIAZINE MOLECULE}

This type of molecule is characterized by the $\mathrm{C}_{3}$ symmetry and has three azido groups, each of which has the ability to dissociate with the release of molecular nitrogen. It is clear that the dissociation process occurs with a decrease in the symmetry of the molecule. This creates nitrene, a molecule with a single $\mathrm{C}-\mathrm{N}$ bond and two unbound molecular orbitals (MOs) located on the nitrogen atom. One MO is localized in these MOs, as a result of which the ground state of nitrene is the triplet state.

Table 1 - Excitation parameters of the TAT molecule from the basic geometric configuration

\begin{tabular}{|c|c|c|c|c|c|c|}
\hline State & $E, \mathrm{eV}$ & & MO & Type & $\lambda, \mathrm{nm}$ & $f$ \\
\hline $\mathrm{S}_{0}$ & -70.5901 & & & & & \\
\hline $\mathrm{T}_{1}$ & -68.1203 & $\begin{array}{ll}36 & - \\
35 & - \\
34 & -\end{array}$ & $\begin{array}{ll}-> & 38 \\
--> & 37 \\
-> & 42\end{array}$ & $\Pi \rightarrow \Pi^{*}$ & 502.0 & 0 \\
\hline $\mathrm{T}_{2}$ & -67.918 & $34-$ & $->\quad 37$ & $\Pi \rightarrow \Pi^{*}$ & 464.0 & 0 \\
\hline $\mathrm{T}_{3}$ & -67.9174 & 34 & $\rightarrow>38$ & $\Pi \rightarrow \Pi^{*}$ & 463.9 & 0 \\
\hline $\mathrm{T}_{4}$ & -67.8723 & $\begin{array}{ll}35 & - \\
35 & - \\
34 & -\end{array}$ & $\begin{array}{ll}--> & 39 \\
--> & 40 \\
--> & 40\end{array}$ & $\Pi \rightarrow \sigma^{*}$ & 456.2 & 0 \\
\hline $\mathrm{T}_{5}$ & -67.8651 & $\begin{array}{ll}36 & - \\
34 & -\end{array}$ & $\begin{array}{ll}-> & 39 \\
-> & 41 \\
\end{array}$ & $\Pi \rightarrow \sigma^{*}$ & 455.0 & 0 \\
\hline $\mathrm{T}_{6}$ & -67.8645 & $\begin{array}{l}36 \\
34\end{array}$ & $\begin{array}{ll}-> & 41 \\
-> & 39\end{array}$ & $\Pi \rightarrow \sigma^{*}$ & 454.9 & 0 \\
\hline $\mathrm{T}_{7}$ & -67.3621 & 36 & $->\quad 43$ & $\Pi \rightarrow \Pi^{*}$ & 384.1 & 0 \\
\hline $\mathrm{T}_{8}$ & -67.0847 & 36 & $->\quad 45$ & $\Pi \rightarrow \Pi^{*}$ & 353.7 & 0 \\
\hline $\mathrm{S}_{1}$ & -67.5734 & $\begin{array}{ll}35 & - \\
34 & -\end{array}$ & $\begin{array}{ll}-> & 40 \\
-> & 39 \\
\end{array}$ & $\Pi \rightarrow \sigma^{*}$ & 411.0 & 0.0001 \\
\hline $\mathrm{S}_{2}$ & -67.569 & 34 & $->\quad 40$ & $\Pi \rightarrow \sigma^{*}$ & 410.6 & 0.0002 \\
\hline $\mathrm{S}_{3}$ & -67.5675 & $\begin{array}{ll}36 & - \\
34 & -\end{array}$ & $\begin{array}{ll}-> & 39 \\
-> & 41 \\
\end{array}$ & $\Pi \rightarrow \sigma^{*}$ & 410.2 & 0.0000 \\
\hline $\mathrm{S}_{4}$ & -66.6073 & 34 & $->\quad 37$ & $\Pi \rightarrow \Pi^{*}$ & 311.3 & 0.3921 \\
\hline $\mathrm{S}_{5}$ & -66.606 & 34 & $->\quad 38$ & $\Pi \rightarrow \Pi^{*}$ & 311.2 & 0.3942 \\
\hline $\mathrm{S}_{6}$ & -66.5436 & $\begin{array}{ll}36 & - \\
35 & -\end{array}$ & $\begin{array}{ll}-> & 38 \\
-> & 37 \\
\end{array}$ & $\Pi \rightarrow \Pi^{*}$ & 306.4 & 0.0001 \\
\hline $\mathrm{S}_{7}$ & -66.5223 & 36 & $->\quad 45$ & $\Pi \rightarrow \Pi^{*}$ & 304.8 & 0.0019 \\
\hline
\end{tabular}

The study of the energy structure of the TAT molecule was performed using the semi-empirical quantum mechanical method for calculating MNDO, created by a group of authors [10] for the calculation of molecules containing elements of the first and second rows of the periodic table. This method allows you to calculate the energy structure of a molecule, the type of MOs for each state of the molecule and the strength of the quantum transition oscillator. In our case, 36 fully filled MOs are taken into account for the calculation. When performing calculations of excited states, the configurational interaction between 12 filled and 12 free MOs is taken into account.

Table 1 shows the results of the calculations. The binding energy of electrons localized at $36 \mathrm{MO}$ with the TAT molecule was chosen as the starting point. The table shows that the symmetry of the molecule determines the fact that the energy levels of the excited states are triples. In this case, three lower triplet levels are represented by $\Pi \rightarrow \Pi^{*}$ quantum transitions, the next three levels - by $\Pi \rightarrow \sigma^{*}$ transitions. In [8], it was shown that the processes of dissociation of a molecule into fragments are possible only from $\Pi \sigma^{*}$-states. Therefore, one of the $\mathrm{T}_{4}, \mathrm{~T}_{5}$ or $\mathrm{T}_{6}$ levels will be responsible for the dissociation of the azido group upon excitation of the TAT molecule.
Similar studies of singlet quantum transitions in the TAT molecule have shown that the first three energy levels are represented by $\Pi \rightarrow \sigma^{*}$ transitions, and the following - by $\Pi \rightarrow \Pi^{*}$ transitions. Since one of the first three levels will be responsible for the dissociation of the molecule, it can be expected that the quantum yield of such a process will be close to one.

Let us see how the wave functions of the excited states of the TAT molecule are formed. They have the following appearance:

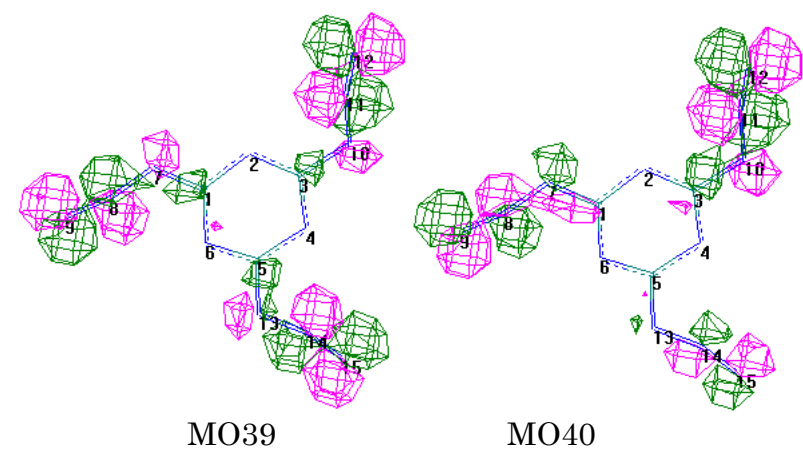




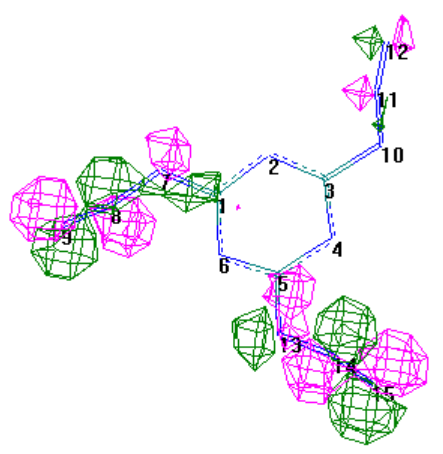

MO41

The structure of $\sigma^{*}$-MO of the excited states is given here. These states are obtained as a result of the configurational interaction between three quantum transitions of the same symmetry. Each $\sigma^{*}$-MO of a separate azido group is localized on the corresponding azido group. The configurational interaction between them leads to the formation of a symmetric MO39, which is responsible for the lower triplet $\sigma^{*}$-state of the molecule. Herewith the $\mathrm{C}_{3}$ symmetry of the molecule is preserved. The next two $\sigma^{*}$ MOs will be created due to the antisymmetric combination between the two MOs, namely $\sigma_{1}{ }^{*}-\sigma_{3}{ }^{*}$ and $\sigma_{1}{ }^{*}-\sigma_{5}{ }^{*}$, where indices 1,3 and 5 mark the positions of the azido group relative to the six-membered ring. Both of these MOs have reduced symmetry and may be responsible for the dissociation of the azido group.

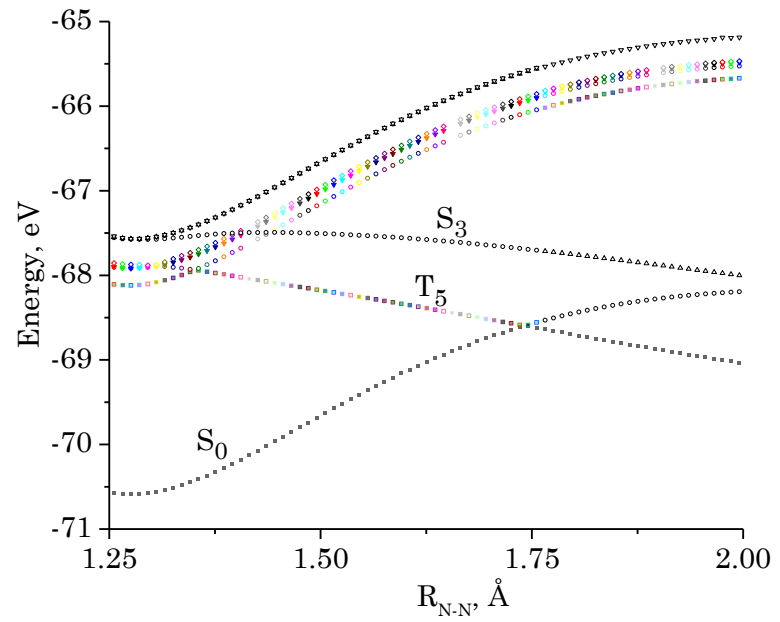

Fig. 1 - Energy diagram of the triazido-S-triazine molecule

\section{THE AZIDO GROUP DISSOCIATION PROCESSES}

From the energy diagram of the TAT molecule in Fig. 1 it follows that dissociative states are states $\mathrm{T}_{5}$ and $\mathrm{S}_{3}$. In this case, the elongation of the $\mathrm{N}-\mathrm{N}$ bond leads to the intersection of the ground state $\mathrm{S}_{0}$ with the state $\mathrm{T}_{5}$, while the state $\mathrm{S}_{3}$ only approaches the ground state $\mathrm{S}_{0}$. Thus, the dissociation of the molecule from the state $\mathrm{T}_{5}$ will cause the appearance of nitrene in the ground triplet state, while the dissociation from the state $\mathrm{S}_{3}$ will lead to the formation of nitrene in the excited singlet state.

Let us detail the picture of the formation of a dissociative state. To do this, we will select a narrow range of energies and give diagrams of triplet (Fig. 2) and singlet (Fig. 3) states.

Thus, from Fig. 2 it follows that the excited molecule has the lowest energy at the length of the dissociating bond $R_{\mathrm{N}-\mathrm{N}}=1.275 \AA$. Among the excited states of the molecule, the state $\mathrm{T}_{1}$ has the lowest energy. As the dissociative bond lengthens, the energy of this state only increases. Similarly, the energy of states $\mathrm{T}_{2}$ and $\mathrm{T}_{3}$ increases. Interestingly, the energy of the state $\mathrm{T}_{4}$, which corresponds to the quantum transition to the symmetric $\sigma^{*}-\mathrm{MO}$, also increases. The antisymmetric $\sigma^{*}$-MO of the state $\mathrm{T}_{5}$ turned out to be dissociative. Moreover, it crosses alternately all the lower triplet states as the length $R_{\mathrm{N}-\mathrm{N}}$ increases. The reduced symmetry of the molecule allows such an interaction to manifest itself with the splitting of energy states in the region of intersection of energy states. This process is most visible in the intersection of states $\mathrm{T}_{5}$ and $\mathrm{T}_{1}$. The splitting value in this case is $0.023 \mathrm{eV}\left(184 \mathrm{~cm}^{-1}\right)$. With such a small energy splitting, the dissociation process in this place is likely to remain non-equilibrium. It will be nonequilibrium at the intersection of the state $\mathrm{T}_{5}$ with states $\mathrm{T}_{4}, \mathrm{~T}_{3}$ and $\mathrm{T}_{2}$, where the energy gap is even smaller. However, in this case, a competitive process is possible - the relaxation of the molecule into the state $\mathrm{T}_{1}$.

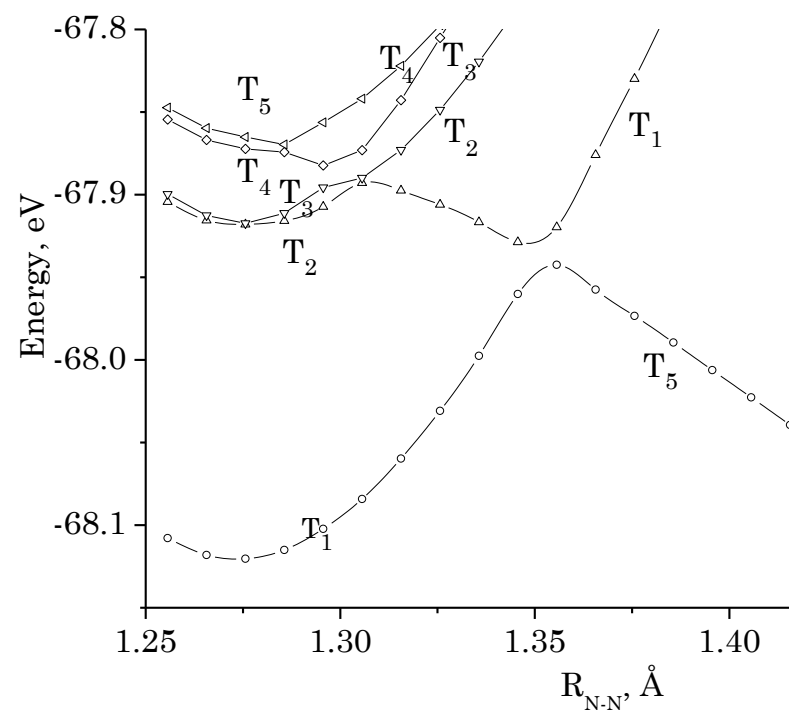

Fig. 2 - Energy diagram of triplet states of the TAT molecule

It remains to understand how the state $\mathrm{T}_{5}$ is populated after excitation of the molecule.

From Table 1, it follows that excitation of the molecule occurs into states $\mathrm{S}_{4}$ and $\mathrm{S}_{5}$, which are significantly distant from states $\mathrm{S}_{1}, \mathrm{~S}_{2}$ and $\mathrm{S}_{3}$. These states are characterized by a binding energy diagram. Relaxation of excitation from states $\mathrm{S}_{4}$ and $\mathrm{S}_{5}$ will occur in the oscillating process in states $\mathrm{S}_{1}, \mathrm{~S}_{2}$ and $\mathrm{S}_{3}$. Subsequent relaxation processes will transfer energy to the state $\mathrm{S}_{3}$, as the energy of this state decreases rapidly when the $\mathrm{N}-\mathrm{N}$ bond is lengthened to $1.3 \AA$.

As follows from Fig. 3, the state $\mathrm{S}_{3}$ becomes dissociative only after elongation of the $\mathrm{N}-\mathrm{N}$ bond to $1.43 \AA$. The barrier height is $0.083 \mathrm{eV}$. Its presence reduces the probability of transition of the electronic system to the dissociative state by 27 times at room 
temperature. In this case, competition with interconversion to the triplet $\Pi \sigma^{*}$-state is possible. In this regard, it is important to note that the quantum yield of interconversion between $п \sigma^{*}$-states significantly increases [8].

On the way to the dissociation of the azido group from the triplet state $\mathrm{T}_{5}$, there is a process of relaxation to the state $\mathrm{T}_{1}$, as a result of which the resulting quantum yield can be significantly reduced. Experimental studies show that the quantum yield of TAT photodissociation in liquid and solid solutions is, respectively, 0.34 and 0.3 .

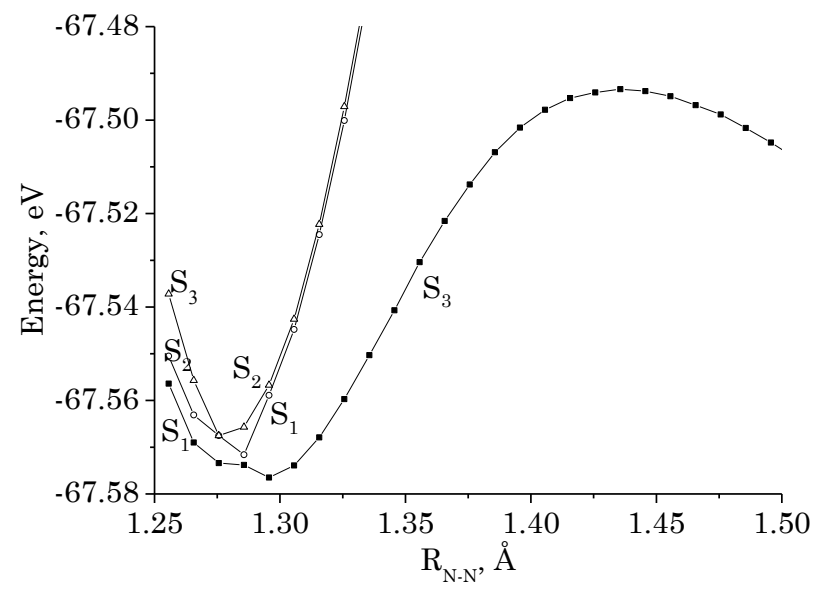

Fig. 3 - Energy diagram of singlet states of the TAT molecule

A study of the MO configuration of nitren showed that the ground state corresponds to the $\sigma^{*}$-MO localized on the nitrogen atom, while the other two $\sigma^{*}$ MOs located on the two azido groups correspond to the excited states. This situation provides a rapid internal conversion of excitation energy to the ground state. Therefore, during the lifetime of nitrene, the photochemical activity of this molecule will be suppressed. However, nitrene quickly attaches an oxygen molecule to a nitrogen atom to form a nitro group or is

\section{REFERENCES}

1. M. Terrones, N. Grobert, J. Olivares, J.P. Zhang, H. Terrones, K. Kordatos, W.K. Hsu, J.P. Hare, P.D. Townsend, K. Prassides, A.K. Cheetham, H.W. Kroto, D.R.M. Walton, Nature 388, 52 (1997).

2. T. Utschig, M. Schwarz, G. Miehe, E. Kroke, Carbon 42 No 4,823 (2004).

3. M.I. Lucío, F. Pichler, J.R. Ramírez, A. de la Hoz, A. SánchezMigallón, C. Hadad, M. Quintana, A. Giulani, M.V. Bracamonte, J.L.G. Fierro, C. Tavagnacco, M.A. Herrero, M. Prato, E. Vázquez, Chemistry - A European Journal 22 No 26, 8879 (2016).

4. Q.-L. Yan, M. Gozin, F.-Q. Zhao, A. Cohen, S.-P. Panget, Nanoscale 8, 4799 (2016).

5. C. Ye, H. Gao, J.A. Boatz, G.W. Drake, B. Twamley, J.M. incorporated into the $\mathrm{C}-\mathrm{H}$ bond of a molecule of a solid or liquid solvent. In this case, the photochemical activity of the formed molecule continues.

\section{CONCLUSIONS}

Based on theoretical studies and analysis of experimentally obtained data on the photochemical activity of the triazido-S-triazine molecule, the following is shown.

1. The spatial structure of the molecule leads to the threefold character of the energy structure of the molecule, and the molecule has the lowest energy in the first three triplet $п \Pi^{*}$-states.

2. Relaxation of the excited molecule from the пп* state to the $\Pi \sigma^{*}$-state can lead to dissociation of the molecule, as well as to the conversion of the molecule into triplet $п \sigma^{*}$-states, that is facilitated by the $п \sigma^{*}$ configuration of the singlet state of the molecule.

3. There are three energy levels of the excited states as a result of the configurational interaction between three local по*-states. The lowest of them corresponds to the $\mathrm{MO}$ which has $\mathrm{C}_{3}$ symmetry.

4. The curves of the potential surfaces of $\Pi \Pi^{*}$-states and lower $\Pi \sigma^{*}$-states provide the binding of atoms in the molecule, i.e. the stabilization of its structure.

5. $\Pi \sigma^{*}$-states, which correspond to the reduced symmetry of the MO, can have a potential surface of a dissociative nature. It turned out that among the triplet $\Pi \sigma^{*}$-states, the second state, i.e. the state $\mathrm{T}_{5}$, is dissociative, while among the singlet $\Pi \sigma^{*}$-states - the state $\mathrm{S}_{3}$.

6. During the elongation of the $\mathrm{N}-\mathrm{N}$ bond the dissociative surface intersects with lower energy surfaces, as a result of which energy transfer between states is possible, which causes a decrease in the quantum yield of dissociation of the azido group.

7. Upon dissociation of the molecule from the singlet state, nitrene in the excited singlet state is formed, while upon dissociation from thre triplet state - in the basic triplet state.
Shreeve, Angew. Chemie 45 No 43, 7262 (2006).

6. J.C. Oxley, J.L. Smith, J.S. Moran, J. Energetic Mater. 27 No 2, 63 (2009).

7. S.S. Machakanur, B.R. Patil, D.S. Badiger, R.P. Bakale, K.B. Gudasi, S.W. Annie Bligh, J. Molec. Struct. 1011, 121 (2012).

8. P.O. Kondratenko, Fotohimichna diya suitla (Kyiv: VPC "Kiyvsky universitet": 2005) [Photochemical action of light] [in Ukrainian].

9. P.O. Kondratenko, Yu.M. Lopatkin, T.N. Sakun, J. NanoElectron. Phys. 4 No 2, 02017 (2012)

10. M.J.S. Dewar, W. Thiel, J. Am. Chem. Soc. 99 15, 4899 (1977). 


\title{
Механізми релаксації електронного збудження триазидо-S-триазину
}

\author{
П.О. Кондратенко ${ }^{1}$ Ю.М. Лопаткін ${ }^{2}$, Т.М. Сакун ${ }^{1}$
}

${ }^{1}$ Національний авіаційний університет, просп. Люболира Гузара, 1, 03058 Київ, Украӥна ${ }^{2}$ Сулський державний університет, вул. Рилського-Корсакова 2, 40007 Сули, Украӥна

Відкриття фулеренів і ідентифікація вуглецевих нанотрубок стали етапом у розвитку матеріалознавства, приладобудування і нової нанотехнології. В результаті проведених досліджень механізмів релаксації електронного збудження в симетричних молекулах триазидо-S-триазину показано, що $\mathrm{C}_{3}$ симетрія молекули зумовлюе той факт, що енергетичні рівні збуджених станів виступають трійками. Серед триплетних станів найнижчу енергію мають перші три пп*-стани, за ними знаходяться три по*-стани. Серед синглетних станів найнижчу енергію мають перші три по*-стани. Наступні стани $\epsilon$ пп*-станами, відповідальними за спектри УФ поглинання молекули. Збудження молекули в ці стани швидко релаксуе в по*-стани, з яких можливе протікання процесів дисоціації молекули. 3 іншого боку, по* конфігурація синглетних станів сприяе швидкій конверсії молекули в триплетні по*-стани. Показано, що конфігураційна взаємодія між трьома локальними по*-станами приводить до створення трьох делокалізованих молекулярних орбіталей (МО). При цьому створюються три енергетичні рівні збудженого стану, найнижчому з яких відповідае MO, яка мае $\mathrm{C}_{3}$-симетрію. Інші дві MO мають понижену симетрію, а тому саме вони відповідальні за дисоціацію молекули. Виявилось, що дисоціативну потенціальну поверхню мають стани $\mathrm{T}_{5}$ та $\mathrm{S}_{3}$. Взаемодія між станами спричинюе пониження квантового виходу фотодисоціації молекули.

Ключові слова: Релаксація електронного збудження, Високозбуджені стани, Дисоціативна потенціальна поверхня, Конфігураційна взаємодія, Фотодисоціація азидів. 